exchange of classified and unclassified information on research in the field of controlled thermonuclear reactions has been agreed. A party of scientists from Harwell visited the United States in October 1956 to see and discuss work in this field, and a party of scientists from the United States made a return visit in the following month to Harwell and to the laboratories of Associated Electrical Industries, Ltd., where work is being done under contract for the Atomic Energy Authority. About ten British scientists will take part in a classified conference on the subject which has been organized by the United States Atomic Energy Commission in Berkeley, California, starting on February 20.

\section{Atomic Age Studies at Columbia University}

CoxUMBIA University has announced the creation of a Council for Atomic Age Studies, with the objective of making the University a centre for the study of problems facing society as a result of the development of atomic energy, problems which in many instances overlap a number of fields of activity and different branches of learning. Fields of study represented on the Council itself include physics, engineering, medicine, international relations, journalism, business, philosophy and law. Prof. I. I. Rabi, Higgins professor of physics, and Prof. P. C. Jessup, Hamilton Fish professor of international law and diplomacy, have been designated co-chairmen.

The Council will initiate, organize and supervise studies, drawing on the competence of many disciplines and activities of the University to examine some of the effects of the development of atomic energy on such diverse areas as industry, law, economics, foreign policy, international relations, agriculture, physical and mental health, domestic economy, city planning and community life. (The effects of such areas in turn on atomic development may also require study.) Possible studies include various issues in the international development of atomic power which involve research in technology, law, economics and foreign policy. Similarly, there is need to consider in joint studies the effect of new forms and sources of power on industry and agriculture, on physical and mental health, and on the domestic economy and the life of communities.

\section{Botany at University College, London :}

Prof. W. H. Pearsall, F.R.S.

Prof. W. H. Pearsall, who attained the age of retirement last year, succeeded Sir Edward Salisbury as Quain professor of botany at University College, London, in 1944. Previously he had occupied the chair of botany at the University of Sheffield for seven years and prior to that had been lecturer in the University of Leeds. During his tenure of the Quain chair, the Botany Department shared in the general post-war expansion of science departments at University College, with its consequent problems of congestion. The bomb damage suffered by the College inevitably delayed the necessary expansion and Prof. Pearsall had to cope with the interim expedients while his successor will enjoy the benefits of the provision which Prof. Pearsall planned. Despite these and other University preoccupations, Prof. Pearsall found time to serve on a number of scientific bodies. He took a prominent part in the development of the Freshwater Biological Station at Windermere, especially in its early years; he was a very active member of the British Ecological Society, of which he became president and for some years effectively edited its Journal; also since 1947 he has edited the Annals of Botany. Prof. Pearsall has made important contributions to plant physiology and to the study of the ecology of freshwaters and moorlands. He was elected a Fellow of the Royal Society in 1940 and has twice served on its Council.

Dr. D. Lewis, F.R.S.

DR. DAN I,EWIS has been appointed Quain professor of botany at University College, London, in succession to Prof. Pearsall. Dr. Lewis went to the John Innes Horticultural Institution when it was at Merton in 1935. Until 1948 he worked in the Pomology Department. At first he was concerned with the general breeding of fruits, but soon he concentrated his attention on the prob. lem of incompatibility. In the course of this work he developed a combination of physiological and genetic techniques which brought a new understanding of gene action and of gene evolution. Splitting the incompatibility gene and comparing the frequencies of natural and induced mutation in pollen were two examples of his experimental skill. Later, Dr. Lewis has applied his own methods and his own point of view to the study of cytoplasmic heredity, heterosis, and breeding systems in flowering plants and fungi. In every direction he has shown a gift for extracting fundamental principles from practical problems. Dr. Lewis became head of the Genetics Department at the John Innes Institution in 1948 and was elected a Fellow of the Royal Society in 1954. His appointment as head of a university department, the sixth to be made from the staff of the John Innes Horticultural Institution in the past ten years, should prove stimulating and fruitful for both parties.

\section{Biology at the Massachusetts Institute of Tech- nology : \\ Prof. I. W. Sizer}

Prof. IrwiN W. Stzer has been appointed head of the Department of Biology at the Massachusetts Institute of Technology. Prof. Sizer, who is well known for his studies of the fundamental properties and medical applications of enzymes, is at present studying the use of enzyme inhibitors as antibiotics and in chemotherapy. He is also doing research on the medical aspects of enzymes as related to skin grafting in the treatment of severe burns. Prof. Sizer has also studied extensively enzymes which are concerned with the clotting of blood, and others which bring about the oxidation and destruction of the toxic irritants of poison ivy. In addition, he has worked on the spectroscopy and biochemistry of collagen and has done research in connexion with the use of sheep gut, of which collagen is the principal constituent, for surgical sutures. A native of Bridgewater (Massachusetts), Prof. Sizer received his A.B. from Brown University in 1931 and his $\mathrm{Ph} . \mathrm{D}$. from Rutgers University in 1935. He went to the Massachusetts Institute of Technology in 1935 as lecturer in biology and public health, became an associate professor in 1942 and executive officer of the Department in 1954. He became acting head of the Department in 1955 and was appointed full professor in 1956 .

\section{Science at Unesco}

UNDER the title "Ten Years of Science at Unesco", Prof. M. Florkin has contributed to the issue of 